RASĀYAN J. Chem.

Vol. 13 | No. 4 |2626-2632| October - December | 2020 ISSN: 0974-1496 | e-ISSN: 0976-0083 | CODEN: RJCABP

\title{
DESIGN OF THIOXANTHONE DERIVATIVES AS POTENTIAL TYROSINE KINASE INHIBITOR: A MOLECULAR DOCKING STUDY
}

\author{
F. Hermawan ${ }^{1,2}$, J. Jumina ${ }^{1, *}$ and H.D. Pranowo ${ }^{1,2}$ \\ ${ }^{1}$ Department of Chemistry, Faculty of Mathematics and Natural Sciences, Universitas Gadjah \\ Mada, Yogyakarta-55281, (Yogyakarta) Indonesia \\ ${ }^{2}$ Austrian-Indonesian Centre (AIC) for Computational Chemistry, Department of Chemistry, \\ Faculty of Mathematics and Natural Sciences, Universitas Gadjah Mada, Sekip Utara, \\ Yogyakarta-55281, (Yogyakarta) Indonesia \\ *E-mail: jumina@ugm.ac.id
}

\section{ABSTRACT}

Xanthone derivatives have been well-known for their wide and outstanding bioactivity so far. However, investigation of thioxanthone derivatives and their biological activity is rarely reported. In this work, molecular docking analysis was conducted to evaluate the thioxanthone activity as a tyrosine kinase inhibitor (PDGFR, EGFR). Six thioxanthone derivatives (A-F) were optimized using Gaussian 09 with a semi-empirical method and were docked to the receptor using AutoDock4 software. The free binding energy of thioxanthone derivatives was ranging from -7.10 to -8.57 and -6.23 to $-7.25 \mathrm{kcal} \mathrm{mol}^{-1}$ against PDGFR and EGFR. Docking result of all thioxanthone derivatives into PDGFR protein exhibited higher binding energies than that of imatinib, whereas docking result into EGFR protein of all thioxanthone derivatives (except for compound A) gave lower binding energies than that of erlotinib. Among the analyzed compounds, compound 4-iodo-1,3-dihydroxythioxanthone (F) exhibits the lowest binding energy in both tyrosine kinase inhibitors due to its ability to form a Hydrogen bond to the PDGFR receptor with the side chain of Cys673 and the EGFR receptor with the side chain Met796 amino acid residue. This result indicated that compound $\mathrm{F}$ has a stronger interaction in tyrosine kinase inhibitor thus promising for a new candidate of anticancer agent.

Keywords: Molecular Docking, Thioxanthone, PDGFR, EGFR, AutoDock.

CC RASĀYAN. All rights reserved

\section{INTRODUCTION}

Cancer is the second serious disease that causes death in the world. In 2018, cancer is responsible for 9.6 million deaths. ${ }^{1}$ The cancer cells attack and destroy adjacent tissues and metastasize to other parts of the human body. ${ }^{2}$ The main problems of the cancer disease are resistance, lack of selectivity, and the occurrence of side effects to chemotherapeutic agents. ${ }^{3}$ Hence it is highly necessary to develop new anticancer agents to solve this problem. Even though hundreds of anticancer agents have been synthesized and evaluated, their anticancer activity was not satisfied. Protein-tyrosine kinases (PTKs) are the key intermediates in cell signaling pathways that control cell growth and apoptosis. Some pathological disorders, including unregulated cell proliferation, is caused by changed functions of individual protein kinases. ${ }^{4}$ Inhibitors of tyrosine kinase can be contemplated as a target for antiangiogenesis and applied as a new cancer therapy model.

Inhibitors of tyrosine kinase-like platelet-derived growth factor receptor (PDGFR) and epidermal growth factor receptor (EGFR) kinase have been confirmed for their critical role in cancer. PDGFR protein is involved in the cancer cell survival and proliferation stage. PTK Inhibitors such as imatinib could block the activity of platelet-derived growth factor (PDGFR or C-Kit PTK). ${ }^{5}$ Meanwhile for EGFR protein could influence tumor growth including metastasis, angiogenesis, proliferation, and inhibition in the apoptosis process. ${ }^{6}$ By using tyrosine kinase inhibitors such as erlotinib, the activity of EGFR protein could be inhibited. This inhibitor interacts with the ATP binding site through Hydrogen bonding, thereby blocking signal transduction from the EGFR. ${ }^{7}$ The systematic and scientific strategy to the discovery of novel and

Rasayan J. Chem., 13(4), 2626-2632(2020)

http://dx.doi.org/10.31788/ RJC.2020.1345699

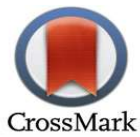


RASĀYAN J. Chem.

Vol. 13 | No. 4 |2626-2632| October - December | 2020

potent drugs is molecular docking of the new compound against the active receptor site. ${ }^{8}$ Molecular docking could predict orientations (conformations) and interaction between two molecules precisely, as shown by the formation of a stable complex. This method provides a tool to investigate and explore many new drug candidates for the same receptor at the same time. The new drug that has a better interaction between a ligand and a receptor will be chosen for use in laboratory experiments. So this method could save resources and is less time-consuming. ${ }^{9}$ The best confirmation is determined by the binding affinity or binding energies of the target molecule against the active receptor. The lowest binding energy is associated with the strongest interaction. ${ }^{10}$ AutoDock program was used to predict and rank the structures arising from the interaction between ligand and a target protein in a 3D structure. ${ }^{11}$

The search of new compounds as an inhibitor of PDGFR and EGFR protein could be seen from the cocrystal structures of imatinib and erlotinib. From those structures, the binding pose of inhibitor with protein could be studied and used to design new bioactive compounds that have the same key interaction. The interaction of the compound with protein mainly occurred by the Hydrogen bond. Therefore the bioactive compound must have a Hydrogen bond donor group possessing the ability to interact with the amino acid residue of PDGFR and EGFR protein. The previous study explained that docking of hydroxyxanthone derivatives have Hydrogen bond interaction with PDGFR protein. ${ }^{5}$

Thioxanthone has a similar structure with xanthone, acridone, and anthraquinone tricyclic scaffolds. ${ }^{12-14}$ For many years, derivatives of thioxanthone have been widely investigated and synthesized due to their various biological activities such as antibiotic activity, activation of P-glycoprotein, and especially their antitumor activities. ${ }^{15-17}$ While the other studies reported that chloro-thioxanthone derivatives that have been synthesized have potential as breast anticancer agents. ${ }^{18}$ To the best of the authors' knowledge, docking analysis of thioxanthone derivatives owing to hydroxy and halogen substituents has not been studied for their inhibitor activity. Therefore, this study was conducted to investigate the binding pose and inhibition mechanism of some thioxanthone derivatives with PDGFR and EGFR.

\section{EXPERIMENTAL}

\section{Materials}

Three-dimension (3D) structures of enzymes were taken from the Protein Data Bank database (www.rcsb.org) with PDB ID: 1T46 for PDGFR or C-Kit PTK and 1M17 for EGFR. Imatinib was used as a ligand standard of PDGFR and erlotinib as a ligand standard of the EGFR enzyme. A series of hydroxyand halogen-substituted thioxanthones derivatives (compound A-F) were used as experimental ligands and their structure was shown in Fig.-1. The selection of A-F compounds from thioxanthone derivatives is because those compounds have hydroxy groups that allow the formation of Hydrogen bonds with amino acid residue.

\section{Preparation of Native Ligand and Protein Molecule}

Imatinib as the standard ligand of PDGFR and Erlotinib as the standard ligand of EFGR was downloaded with PDB ID: 1T46 and 1M17. In Chimera, the standard ligand was selected and inverted for all molecules. Then, delete all the selected molecules and saved the PDB format file. Then, the preparation of protein molecules as a receptor was generated using Chimera. Complex of protein-ligand in the PDB (1M17, 1T46) file was cleaned from all residue such as native ligand and water molecules. Then, the protein is saved in the PDB format file.

\section{Optimizing of Thioxanthone Derivatives}

Thioxanthone derivatives A-F in three-dimensional (3D) structures were drawn using GaussView 5.0 and optimized using Gaussian 09 with a semi-empirical method. Then, the structures were saved in the PDB format file. The 2D structure of thioxanthone is shown in Fig.-1.

\section{Redocking Analysis}

Redocking was performed with AutoDock4 in a 50 x 50 x $50 \AA$ grid box using the Lamarckian Genetic Algorithm (LGA). When the RMSD value was $<2 \AA$, this indicated that the redocking analysis was carried out successfully. ${ }^{19}$ 
RASĀYAN $J$. Chem.

Vol. 13 | No. 4 |2626-2632| October - December | 2020

Docking Analysis

All structures that have to optimize from Gaussian were docked in the binding site which is known by redocking analysis. The affinity grid maps size and LGA were set up the same with the redocking analysis.<smiles>O=c1c2ccccc2sc2cc(O)ccc12</smiles>

(A)<smiles>O=c1c2ccccc2sc2c(Cl)c(O)cc(O)c12</smiles>

(D)<smiles>O=c1c2ccccc2sc2cc(O)cc(O)c12</smiles>

(B)<smiles>O=c1c2ccccc2sc2c(Br)c(O)cc(O)c12</smiles>

(E)<smiles>O=c1c2ccccc2sc2c(O)c(O)ccc12</smiles>

(C)<smiles>O=c1c2ccccc2sc2c(I)c(O)cc(O)c12</smiles>

(F)

Fig.-1: Chemical Structures of Thioxanthone Derivatives Involves in the Study. (A) 3-hydroxy thioxanthone, (B) 1,3-dihydroxy-thioxanthone, (C) 3,4-dihydroxy-thioxanthone, (D) 4-chloro-1,3-dihydroxy-thioxanthone, (E) 4bromo-1,3-dihydroxy-thioxanthone, (F) 4-iodo-1,3-dihydroxy-thioxanthone.

\section{Redocking Analysis into Different Protein Tyrosine Kinase}

\section{RESULTS AND DISCUSSION}

Standard ligands were docked into protein tyrosine kinase to visualize the binding pose of protein. The imatinib ligand (STI-571) was docked into PDGFR receptor (PDB ID: 1T46), and it gave the lowest binding energy of $-13.36 \mathrm{kcal} \mathrm{mol}^{-1}$ and showed the best RMSD of $0.61 \AA$. Meanwhile, the docked erlotinib ligand into the EGFR protein exhibited the lowest binding energy of $-6.58 \mathrm{kcal} \mathrm{mol}^{-1}$ and the best RMSD value of $1.17 \AA$. Those results indicated that AutoDock under our experimental parameters is accurate enough since the RMSD values are less than 2. The overlapping structure of native ligand with ligand redocking calculation results can be seen in Fig.-3. The Binding pose of Imatinib ligand to the PDGFR protein took place in amino acid residue Asp810 and Cys673, while erlotinib ligand with EGFR protein was at amino acid residue Met769. Other studies also reported that Imatinib (STI-571) accepts a Hydrogen bond from Asp810 amide nitrogen ${ }^{20}$ and erlotinib accepts Met769 amide nitrogen. ${ }^{21}$ Fig.-2 displayed interactions of native ligand to the receptors.
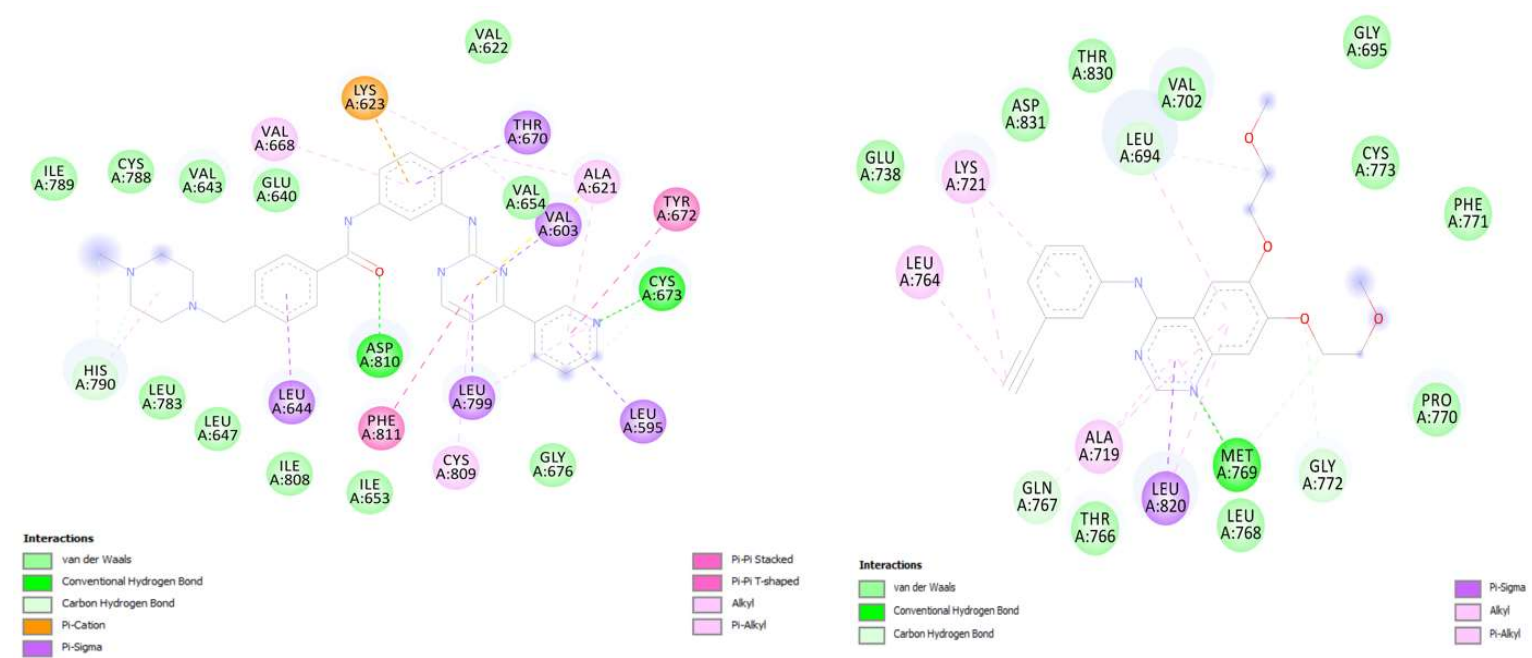

(a)

Fig.-2: The Visualization of Hydrogen Bondings among Docked Ligand with Amino Acid Residues of the Protein (a) Imatinib (b) Erlotinib. 
RASĀYAN $J$. Chem.

Vol. 13 | No. 4 |2626-2632| October - December | 2020

\section{Docking Study of Thioxanthone Derivatives Compounds}

Molecular docking of compounds A-F was carried out using the result of the binding site of redocking analysis. All compounds were set up to have the same position as imatinib (STI-571) and docked into PDGFR protein. Compounds that had low binding energy were $\mathbf{D}, \mathbf{E}$, and $\mathbf{F}$. Those compounds showed the binding energies $-7.92,-7.96$, and $-8.57 \mathrm{kcal} \mathrm{mol}^{-1}$, respectively with RMSD range $0.37-0.46 \AA$ as shown in Table-1. The Hydrogen bond interaction of compounds $\mathbf{D}, \mathbf{E}$, and $\mathbf{F}$ were located in the amino acid residue of Cys673 (see Table-1). The binding pose of those compounds is the same as imatinib from the redocking analysis. The result indicated that those compounds have potential as an inhibitor of PDGFR protein.

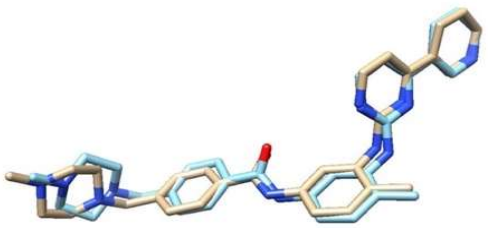

(a)

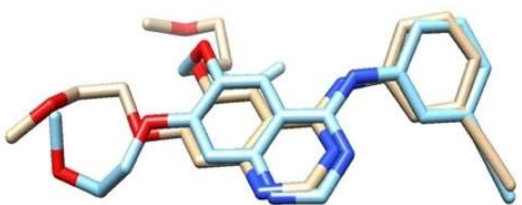

(b)

Fig.-3: The Overlapping Structure of Native Ligand of the X-ray Crystal Structure (white) to the Docking Result (blue) and its RMSD Values ( $<2 \AA$ ) (a) Imatinib (b) Erlotinib.

Table-1: Obtained Docking Results From Compounds A-F and Imatinib with PDGFR.

\begin{tabular}{c|c|c|c|c}
\hline $\begin{array}{c}\text { Conformation of } \\
\text { Compound }\end{array}$ & $\begin{array}{c}\text { Binding Energy } \\
\left(\mathrm{kcal} \mathrm{mol}^{-1}\right)\end{array}$ & $\mathrm{Ki}(\mu \mathrm{M})$ & Hydrogen Bond & RMSD \\
\hline $\mathrm{A}$ & -7.53 & 3.0229 & $\begin{array}{l}\text { Cys673 (1.949) } \\
\text { Thr670 (2.035) }\end{array}$ & 0.23 \\
\hline $\mathrm{B}$ & -7.28 & 4.6098 & $\begin{array}{l}\text { Cys673 (1.896) } \\
\text { Cys673 (2.232) } \\
\text { Thr670 (2.069) }\end{array}$ & 0.35 \\
\hline $\mathrm{C}$ & -7.10 & 6.2463 & $\begin{array}{l}\text { Cys673 (1.986) } \\
\text { Thr670 (2.002) }\end{array}$ & 0.13 \\
\hline $\mathrm{D}$ & -7.92 & 1.5651 & $\begin{array}{l}\text { Cys673 (2.044) } \\
\text { Thr670 (2.047) }\end{array}$ & 0.46 \\
\hline $\mathrm{E}$ & -7.96 & 1.4629 & $\begin{array}{l}\text { Cys673 (1.971) } \\
\text { Thr670 (2.139) }\end{array}$ & 0.37 \\
\hline $\mathrm{F}$ & -8.57 & 0.5225 & $\begin{array}{l}\text { Cys673 (2.051) } \\
\text { Thr670 (2.111) }\end{array}$ & 0.37 \\
\hline Imitinib & -13.36 & 0.0002 & $\begin{array}{l}\text { Asp810 (1.877) } \\
\text { Cys673 (1.874) }\end{array}$ & 0.61 \\
\hline
\end{tabular}

The interaction of those compounds was not just a Hydrogen bond, but there were van der Waals, $\pi$-sigma, and $\pi$-alkyl interactions. These interactions indicated that the interactions between ligand and receptor were positively influenced by the presence of the thioxanthone ring as shown in Fig. $-4 \mathrm{~b}$.



(a)



(b)

Fig.-4: The Binding Affinities Compound F with PDGFR Protein in (a) 3D and (b) 2D Visualization. 
RASĀYAN J. Chem.

Vol. 13 | No. 4 |2626-2632| October - December | 2020

Compound with the best conformation will have the lowest binding energy. Compound $\mathbf{F}$ with iodosubstituent had the lowest binding energy value as well as the inhibition constant. This result suggested that compound $\mathbf{F}$ had the strongest interaction with the protein receptor and indicated that this compound had better anticancer activities. The compound $\mathbf{F}$ bind into PDGFR through up to two Hydrogen bonds which were bound to amino acid residue Cys673 and Thr670 (Fig.-4b).

The molecular docking of thioxanthone derivatives with EGFR protein was arranged in the same position of redocking analysis. The compounds that had low binding energy were $\mathbf{B}, \mathbf{D}, \mathbf{E}$, and $\mathbf{F}$ with binding energies -7.0, -6.87, -7.06, and 7.25 $\mathrm{kcal} \mathrm{mol}^{-1}$, respectively with RMSD range 0.30-0.64 $\AA$ (see Table-2).

Table-2: Docking Results of All Compounds with EGFR.

\begin{tabular}{c|c|c|c|c}
\hline $\begin{array}{c}\text { Conformation of } \\
\text { Compound }\end{array}$ & $\begin{array}{c}\text { Binding Energy } \\
\left(\mathrm{kcal} \mathrm{mol}^{-1}\right)\end{array}$ & Ki $(\mu \mathrm{M})$ & Hydrogen Bond & RMSD \\
\hline $\mathrm{A}$ & -6.23 & 27.124 & Met769 (1.893) & 0.47 \\
\hline $\mathrm{B}$ & -7.00 & 7.3948 & $\begin{array}{l}\text { Glu738 (1.624) } \\
\text { Lys721 (2.094) } \\
\text { Asp831 (2.322) }\end{array}$ & 0.30 \\
\hline $\mathrm{C}$ & -6.36 & 21.780 & $\begin{array}{l}\text { Thr766 (2.601) } \\
\text { Lys721 (1.921) }\end{array}$ & \\
\hline $\mathrm{D}$ & & & Asp831 (1.953) & \\
\hline $\mathrm{E}$ & -6.87 & 9.2091 & Met769(1.781) & 0.28 \\
\hline $\mathrm{F}$ & -7.06 & 6.6826 & $\begin{array}{l}\text { Met769 (1.749) } \\
\text { Thr766 (2.188) }\end{array}$ & 0.66 \\
\hline Erlotinib & -7.25 & 4.8492 & Met769(1.764) & 0.64 \\
\hline
\end{tabular}

The Hydrogen bond interaction of compounds $\mathbf{B}, \mathbf{D}, \mathbf{E}, \mathbf{F}$ were located in the amino acid residue of Met769 (see Fig.-5). This result indicating that these derivative compounds have a correct binding pose due to the same amino acid interaction with the redocking result. The interaction of those compounds was not just a Hydrogen bond, but there were carbon-hydrogen bond and $\pi$-alkyl interactions as shown in Fig.-5b. These interactions indicated that ligand and receptor interactions were enhanced by the presence of thioxanthone ring. Compound with the best conformation had the lowest binding energy and inhibition constant. Compound $\mathbf{F}$ that had iodo-substituent had the lowest binding energy value. This result suggested that compound $\mathbf{F}$ had better stability and the strongest interaction with the protein receptor and indicated had better anticancer activities. The compound $\mathbf{F}$ bind into EGFR through one Hydrogen bond which was bonded to amino acid residue Met769.

\section{Comparison of Native Ligand (imatinib, erlotinib) with Thioxanthone Derivatives}

Table-1 showed that the binding energy of thioxanthone derivatives was higher than that of imatinib showing that the interactions of thioxanthone derivatives with the active site of PDGFR were weaker than imatinib. Whereas Table-2 showed that the binding energy of thioxanthone derivatives (except for compound A) was lower than that of erlotinib. It suggested that thioxanthone derivatives had strong interaction and had better anticancer activity than erlotinib, which is remarkable. These preliminary design and analysis show that thioxanthone derivatives were the potential to be used as tyrosine kinase inhibitor shortly.

\section{CONCLUSION}

A series of thioxanthone derivatives have been studied by using molecular docking simulations to find alternative compounds for future anti-cancer drug candidates. From the results, it was found that compounds $\mathbf{B}, \mathbf{D}, \mathbf{E}, \mathbf{F}$ gave lower binding energy than erlotinib demonstrating that those compounds have a strong interaction in EGFR protein. Among the six thioxanthone derivatives, compound $\mathbf{F}$ gave the lowest binding energy in both PDGFR and EGFR proteins. This result indicated that compound $\mathbf{F}$ has a stronger interaction in protein PDGFR and EGFR, and had better anticancer activities. The binding pose of compound $\mathbf{F}$ took place in amino acid residue Cys673 for protein PDGFR and Met769 for EGFR with a distance of Hydrogen bond in range 1.7 until $2.1 \AA$. 
RASĀYAN J. Chem.

Vol. 13 | No. 4 |2626-2632| October - December | 2020

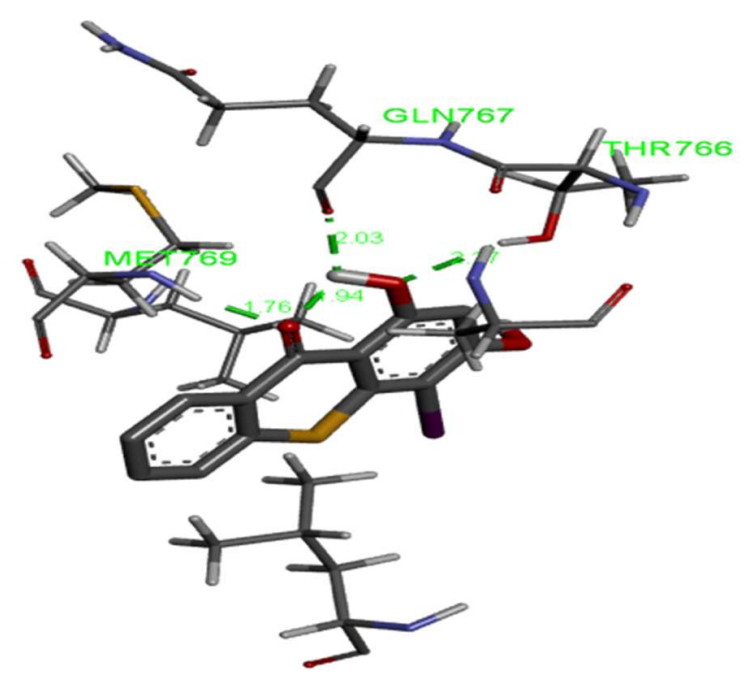

(a)



(b)

Fig.-5: The Binding Affinities of Compound F with EGFR Protein (a) 3D (b) 2D Visualization.

\section{ACKNOWLEDGEMENT}

The authors would like to deeply thank KEMRISTEKDIKTI for the financial support for this research and the Pendidikan Magister Menuju Doktor Untuk Sarjana Unggul (PMDSU) scholarship for Faris Hermawan. We also sincerely thank for the Gaussian 09 licenses provided by Austrian-Indonesian Centre (AIC) for computational chemistry.

\section{REFERENCES}

1. https://www.who.int/en/news-room/fact-sheet/detail/cancer.

2. R. Vadlakonda, R. Nerella, and S. V. Srinivas, Rasayan Journal of Chemistry, 10(4), 1316(2017), DOI:10.7324/RJC.2017.1041914

3. T. D. Wahyuningsih, A. A. T. Suma, and E. Astuti, Journal of Applied Pharmaceutical Science, 9, 14(2019), DOI:10.7324/JAPS.2019.90303

4. D. Wei, X. Jiang, L. Zhou, J. Chen, Z. Chen, C. He, K. Yang, Y. Liu, J. Pei, and L. Lai, Journal of Medicinal Chemistry, 51, 7882(2008), DOI: 10.1021/jm8010096

5. E. Yuanita, H. D. Pranowo, Mustofa, R. T. Swasomo, J. Syahri, and Jumina. Chemistry Journal of Moldova, 14, 68(2019), DOI:10.19261/cjm/2018.520

6. J. Baselga, Oncologist, 7, 2 (2002), DOI:10.1634/theoncologist.7-suppl_4-2

7. R. S. M. Ismail, N. S. M. Ismail, S. Abuserii, and D. A. A. El-Ella, Future Journal of Pharmaceutical Sciences, 2, 9(2016), DOI:10.1016/j.fjps.2016.02.001

8. S. Ganguly, S. Murugesan, Rasayan Journal of Chemistry,1(2), 251(2008)

9. B. Mukesh, and K. Rakesh, International Journal of Research in Ayurveda and Pharmacy, 2, 1746(2011)

10. S. S. Murthy, and T. B. Narsaiah, Rasayan Journal of Chemistry, 12(4), 2030(2019), DOI: 10.31788/RJC.2019.1245475

11. S. F. Sousa, P. A. Fernandes, and M. J. Ramos, Proteins, 65, 15(2006), DOI:10.1002/prot.21082

12. N. Pouli, and P. Marakos, Anti-Cancer Agents in Medicinal Chemistry, 9, 77(2009), DOI:10.2174/187152009787047699

13. P. Belmont, and I. Dorange, Expert Opinion on Therapeutic Patents, 18, 1211(2008), DOI:10.1517/13543776.18.11.1211

14. Q. Huang, G. Lu, H. M. Shen, M. C. Chung, and C. N. Ong, Medicinal Research Review, 27(5), 609(2007), DOI: 10.1002/med.20094

15. L. J. Bessa, A. Palmeira, A. S. Gomes, V. Vasconcelos, E. Saousa, M. Pinto, and P. Martin da costa, Microbial Drug Resistance, 21, 404(2015), DOI:10.1089/ mdr.2014.0162 
RASĀYAN J. Chem.

Vol. 13 | No. 4 |2626-2632| October - December | 2020

16. R. Silva, A. Palmeira, H. Carmo, D. J. Barbosa, M. Gameiro, A. Gomes, A. M. Paiva, E. Sousa, M. Pinto, M. L. Bastol, and F. Remiao, Archives of Toxicology, 89, 1783(2015), DOI:10.1007/s00204014-1333-4

17. A. Palmeira, M. H. Vasconcelos, A. Paiva, M. X. Fernandes, M. Pinto, and E. Sousa, Biochemical Pharmacology, 83, 57(2012), DOI: 10.1016/j.bcp.2011.10.004

18. C. -L. Chen, T. -C. Chen, C. -C. Lee, L. -C. Shih, C. -Y. Lin, Y. -Y. Hsieh, A. A. A. Ali, and H. -S. Huang, Arabian Journal of Chemistry, (2015), DOI:10.1016/j.arabjc.2015.10.010

19. R. Huey, G. M. Morris, A. J. Olson, and D. S. Goodsell, Journal of Computational Chemistry, 28, 1545(2007), DOI: $10.1002 /$ jcc.20634

20. M. S. Almutairi, G. H. Hegazy, M. E. Haiba, H. I. Ali, N. M. Khalifa, and A. E. M. Soliman, International Journal of Molecular Sciences, 15, 22580(2014), DOI: 10.3390/ijms151222580

21. Rasyid, R. Armunanto, and B. Purwono, International Journal Applied Science Technology, 10, 293(2017), DOI:10.14416/j.ijast.2017.12.001

[RJC-5699/2020] 